University of Wollongong

Research Online

Faculty of Law, Humanities and the Arts Papers (Archive)

Faculty of Arts, Social Sciences \& Humanities

$1-1-2017$

Neither a Discipline nor a Colony: Renaissance and Re-imagination in Economic History

\author{
Simon Ville \\ University of Wollongong, sville@uow.edu.au \\ Claire Wright \\ University of Wollongong, cw970@uowmail.edu.au
}

Follow this and additional works at: https://ro.uow.edu.au/lhapapers

Part of the Arts and Humanities Commons, and the Law Commons

Research Online is the open access institutional repository for the University of Wollongong. For further information contact the UOW Library: research-pubs@uow.edu.au 


\title{
Neither a Discipline nor a Colony: Renaissance and Re-imagination in Economic History
}

\author{
Abstract \\ After years in the wilderness, economic history is becoming fashionable once more. Intellectual shifts by \\ its parent disciplines of history and economics, the failed experiment of economic history as a separate \\ discipline, and the impact of major economic events have conspired to produce a renaissance in the field \\ of study in the last decade and a half. We explain these changes and show that economic history derives \\ its main strength from its role as an interdisciplinary research field that draws upon and integrates with its \\ closest disciplines. We analyse the nature and recent progress of economic history in Australia and offer \\ a prospective for its future role.

\section{Disciplines} \\ Arts and Humanities | Law

\section{Publication Details} \\ Ville, S. \& Wright, C. (2017). Neither a Discipline nor a Colony: Renaissance and Re-imagination in \\ Economic History. Australian Historical Studies, 48 (2), 152-168.
}




\title{
Neither a Discipline nor a Colony: \\ Renaissance and Re-imagination in Economic History
}

\author{
SIMON VILLE AND CLAIRE WRIGHT
}

After years in the wilderness, economic history is becoming fashionable once more. Intellectual shifts by its parent disciplines of history and economics, the failed experiment of economic history as a separate discipline, and the impact of major economic events have conspired to produce a renaissance in the field of study in the last decade and a half. We explain these changes and show that economic history derives its main strength from its role as an interdisciplinary research field that draws upon and integrates with its closest disciplines. We analyse the nature and recent progress of economic history in Australia and offer a prospective for its future role.

Economic history, it seems, is back in fashion after years in the wilderness, abandoned by its parents who strode off in opposite directions - historians towards culture and economists towards mathematics. The deep historical narratives interrogating language and values sat uncomfortably with the hard-edged causality of economic models.

A reunion appears to be taking place, in America at least, where the divergence was perhaps most notable to begin with. We are told that 'historians are examining the economy again' and 'economic history should be at the heart of economics instruction'. ${ }^{1}$ In Europe there is also much discussion about economic history but with less optimism or agreement Italian Francesco Boldizzoni has announced that economic history is moribund because it has

\footnotetext{
${ }^{1}$ Kenneth Lipartito, 'Reassembling the Economic: New Departures in Historical Materialism', The American Historical Review 121, no. 1 (2016): 101-139, 101; Michael Pettis, 'How Has the Crisis Changed the Teaching of Economics?’ The Economist, 17 September 2010.
} 
been subsumed into economics, while British scholar Nick Crafts, conversely, believes that it is under threat by not paying sufficient heed to economic methods and policy relevance. ${ }^{2}$

In Australia there is now a call to support a 'new materialism' that brings economic history back into the mainstream of historical analysis in ways that embrace both the cultural and the economic rather than implementing a further 'turn'. Australian economic history embraced the econometric turn to a lesser degree than in North America, drawing more upon inductive methods to allow the numbers to speak for themselves. The opportunities for reengagement, therefore, may be stronger here than elsewhere, but there are also challenges ahead.

In the light of these developments, we analyse the reasons for the renewed interest in economic history, the opportunities the field has for re-establishing communication lines with both of its parent disciplines, and evaluate its prospects in Australia.

\section{The rise, fall and revival of economic history}

The twentieth century witnessed the expansion of many fields in the social sciences and humanities. Much of this occurred in the immediate post-WWII decades, when most industrialised nations pursued higher education expansion and reform. ${ }^{4}$ Postwar

\footnotetext{
${ }^{2}$ Francesco Boldizzoni, The Poverty of Clio: Resurrecting Economic History (Princeton: Princeton University Press, 2011); Nicholas Crafts, 'Economic History Matters', Economic History of Developing Regions 27, no. S1 (2012): S3-S15.
${ }^{3}$ Hannah Forsyth and Sophie Loy-Wilson, 'Seeking a New Materialism in Australian History', Australian Historical Studies, this issue.

${ }^{4}$ Hannah Forsyth, A History of the Modern Australian University (Sydney: UNSW Press, 2014); Stuart Macintyre, The Poor Relation (Melbourne: Melbourne University Press, 2010); Roger L. Geiger, Research and
} 
reconstruction schemes, greater occupational professionalisation, higher rates of secondary education, and the perception that a university education was a tool for personal advancement led to increases in student numbers and the resources available to universities. Expansion of the social sciences reflected the interest in postwar reconstruction and social advancement, withthe application of quasi-scientific methods to modern social and economic problems. Economics, sociology and political science all flourished as major social science disciplines, while smaller research fields such as demography, historical sociology, and social anthropology came to the fore by speaking similar languages to the major disciplines and drawing connections among them. ${ }^{5}$

Economic history, employing descriptive statistics and general economic concepts, also forged such links, expanding rapidly in the post-WWII tertiary sector. ${ }^{6}$ In some

Relevant Knowledge: American Research Universities since World War II (New Brunswick: Transaction Publishers, 1993).

${ }^{5}$ Macintyre, The Poor Relation.

${ }^{6}$ Pat Hudson, 'Economic History in Britain: The 'First Industrial Nation', in The Routledge Handbook of Global Economic History, eds, F. Boldizzoni and P. Hudson (London: Routledge, 2015), 17-34; Donald C. Coleman, History and the Economic Past: An Account of the Rise and Decline of Economic History in Britain (Oxford: Clarendon Press, 1987), 105-10; Jean-Yves Grenier, 'Economic History in France: A Sonderweg?', in The Routledge Handbook of Global Economic History, eds, Boldizzoni and Hudson (London: Routledge, 2015 ** please confim if this is a later edn (and if so include edn number) of the same Routledge Handbook cited earlier in this footbote **), 113-29; Ylva Hasselberg, 'Manufacturing the Historic Compromise: Swedish Economic History and the Triumph of the Swedish Model', in The Routledge Handbook of Global Economic History, eds, Boldizzoni and Hudson (London: Routledge, 2015), 146-59; Inaki Iriarte-Goni, 'Spanish Economic History: Lights and Shadows in a Process of Convergence', in The Routledge Handbook of Global Economic History, eds, Boldizzoni and Hudson (London: Routledge, 2015), 160-74; Erik Aerts and Ulbe Bosma, 'The Low Countries, Intellectual Borderlands of Economic History', in The Routledge Handbook of Global Economic History, eds, Boldizzoni and Hudson (London: Routledge, 2015), 175-92; Prasannan 
instances, namely Britain, the Netherlands and Australia, this culminated in the establishment of separate departments of economic history. ${ }^{7}$ In others, such as the United States, France, Belgium, and Japan economic historians generally flourished within economics groups. ${ }^{8}$ Intellectual successes followed, with new methodologies resulting in innovative findings about the long-term process of economic development. ${ }^{9}$ At the same time, economic history's engagement with the lives of ordinary people brought it into contact with social and labour history and streams of Marxist thinking among historians. ${ }^{10}$ Economic history found itself as a key intersection between the social sciences and the humanities.

Parthasarathi, 'The History of Indian Economic History', in The Routledge Handbook of Global Economic History, eds, Boldizzoni and Hudson (London: Routledge, 2015), 281-92.

${ }^{7}$ Jonathan Pincus and Graeme Snooks, 'The Past and Future Role of the Australian Economic History Review: Editorial Reflections and Aspirations', Australian Economic History Review 28, no. 2 (1988): 3-7; Pat Hudson, ed., Living Economic and Social History (Glasgow: Economic History Society, 2001); Donald C. Coleman; Aerts and Bosma.

${ }^{8}$ Aerts and Bosma; Grenier; Naomi Lamoreaux, 'Beyond the Old and the New: Economic History in the United States', in The Routledge Handbook of Global Economic History, eds, Boldizzoni and Hudson (London: Routledge, 2015), 35-54; Kaoru Sugihara, 'Japanese Economic History: Exploring Diversity in Development', in The Routledge Handbook of Global Economic History, eds, Boldizzoni and Hudson (London: Routledge, 2015), 310-28.

${ }^{9}$ Most notably was the wealth of work that constructed and interpreted national income accounts in the $1950 \mathrm{~s}$ and 1960s. See Lamoreaux; Iriarte-Goni; Aerts and Bosma.

${ }^{10}$ For example, Eric J. Hobsbawm, Labouring Men: Studies in the History of Labour (New York: Basic Books, 1965); Eric J. Hobsbawm, The Age of Capital: 1848-1875 (London: Weidenfeld \& Nicolson, 1975); E. P. Thompson, The Making of the English Working Class (New York: Pantheon Books, 1963); Maurice Dobb, Soviet Economic Development Since 1917 (London: Routledge, 1948); Gareth Stedman Jones, Outcast London: A Study in the Relationship Between Classes in Victorian Society (London: Penguin, 1971). 
This embedded position of economic history, however, was short lived since the interests of its main 'parent' disciplines began to change by the 1970s. Economics became increasingly introspective, focussing upon quantitative methodological rigour more than analysing the broader relevance of its causal findings. ${ }^{11}$ History, on the other hand, moved in the direction of a methodological focus infused with language and symbols that recorded the unique rich detail and specificities of each case but with few general lessons to be gleaned from these narratives. ${ }^{12}$

Economic history, nonetheless, edged towards a closer intellectual relationship with the mainstream economics discipline. Most economic historians were located in economics or business faculties, which created expectations for them to conform to the conventions of the economics discipline. Propagated from the United States and known as the "new economic history' (or cliometrics), scholars began applying statistical tests to re-evaluate a range of long held historical perspectives. ${ }^{13}$ Historians were generally unsympathetic to these techniques and the cliometrician's deterministic approach to history, but were increasingly attracted to cultural studies which emphasised the contingent nature of historical events. ${ }^{14}$

\footnotetext{
${ }^{11}$ Carlo M. Cipolla, Between History and Economics: An Introduction to Economic History (Oxford: Basil Blackwell, 1991); Luis Bertola, 'Another Brick in the Wall? A Comment on Francesco Boldizzoni’s The Poverty of Clio', Investigaciones de Historia Económica - Economic History Research 9, no. 1 (2013): 7-10; Grenier; Hudson.

${ }^{12}$ John E. Toews, 'Intellectual History after the Linguistic Turn: The Autonomy of Meaning and the Irreducibility of Experience', The American Historical Review 92, no. 4 (1987): 879-907; Hudson; Lamoreaux; Parthasarathi.

${ }^{13}$ Robert W. Fogel, Railroads and American Economic Growth: Essays in Econometric History (Baltimore: Johns Hopkins Press, 1964); Robert W. Fogel and Stanley L. Engerman, Time on the Cross: The Economics of American Negro Slavery (Boston: Little, Brown and Company, 1974).

${ }^{14}$ Hsu-Ming Teo and Richard White, Cultural History in Australia (Sydney: UNSW Press, 2003).
} 
While the historians drew away from economic history, the economists increasingly regarded economic history, even its 'new' form, as a less rigorous subset of applied economics rather than a distinct field in its own right. ${ }^{15}$

The revival of economic history over the last decade or so might, therefore, come as something of a surprise. It is evidenced not only by the quotations at the start of this paper but by new strands of research and growing student enrolments, particularly in the history of capitalism and global history. Perhaps not surprisingly, millennium economic history is not the same field that fell from grace a quarter of a century earlier. Both revival and reimagination are taking place.

The conjunction of scholarly trends with developments in the global economy largely explains the re-emergence of economic history. A new form of microeconomics was increasingly embraced by the economics profession in the 1990s, which utilised a broader range of qualitative and quantitative measures of progress. This recognised the futility of assumptions of rational human behaviour, the relevance of non-selfish preferences, and the importance of determining how individual life outcomes are affected by long-term circumstances such as friendships, education, health and war. The importance of wellbeing, happiness, and welfare was emphasised, ${ }^{16}$ with endogenous growth theory focussing on the role of human capital, innovation, and knowledge in economic development. ${ }^{17}$ Institutional

\footnotetext{
${ }^{15}$ Claudia Goldin, 'Cliometrics and the Nobel', The Journal of Economic Perspectives 9, no. 2 (1995): 191-208. 16

${ }^{17}$ The Australian Bureau of Statistics (ABS) now uses 26 indices to measure 'progress'. See ABS, Measures of Australia's Progress (Canberra: Government Printer, 2013). There is an ongoing debate about happiness among economists, for example Andrew Leigh and Justin Wolfers, 'Happiness and the Human Development Index: Australia is Not a Paradox', NBER Working Paper, no. 11925 (January 2006). A focus on human capital as an
} 
economics, and its role in international economic development, also gained in popularity, addressing the economic effects of legal, political and social factors. ${ }^{18}$

Historians had always understood the importance of agency, but the lexicon and tools of economics had largely been abandoned with the cultural turn. To some historians, overlooking the economic, material side had left a gap in historical understanding, a void which was partially filled by the history of capitalism movement that developed among American historians from the mid-1990s. Historians had talked about capitalism in the past but mostly to address the rise of the factory system, and its role in the Marxist stages model of development. ${ }^{19}$ In its revived form, the history of capitalism covers a broad range of economic activities and production in a less polarised and linear, more complex and contingent form. ${ }^{20}$

engine of growth has been noted by Paul M. Romer, 'The Origins of Endogenous Growth', The Journal of Economic Perspectives 8, no. 1 (1994): 3-22; Iriarte-Goni.

${ }^{18}$ Institutional economics is particularly associated with Douglass C. North, Institutions, Institutional Change and Economic Performance (Cambridge: Cambridge University Press, 1990). The role of institutions in international development has been seen with comparisons between cities on the border between the United States and Mexico, between North and South Korea, and between different countries in Latin America. See Daron Acemoglu and James A. Robinson, Why Nations Fail: The Origins of Power, Prosperity, and Poverty (New York: Crown, 2012).

${ }^{19}$ Friedrich August Hayek, Capitalism and the Historians (London: Routledge, 1954); Arthur John Taylor, The Standard of Living in Britain in the Industrial Revolution (London: Methuen Publishing, 1975).

${ }^{20}$ For example, Sally H. Clarke, Trust and Power: Consumers, the Modern Corporation, and the Making of the United States Automobile Market (Cambridge: Cambridge University Press, 2007); Roger Horowitz, Putting Meat on the American Table: Taste, Technology, Transformation (Baltimore: Johns Hopkins University Press, 2006). 
Economic history was also in a state of flux. The closure of economic history units in countries like Britain and Australia in the 1990s was part of an institutional shift that forced economic historians to look outwards. Occupying the space left by the prior shifts of economics and history, economic history's boundaries became more porous as scholars began to seek out relationships with a range of close disciplines and fields such as business history, demography, organisational studies, sociology, critical management studies, and anthropology.

Events beyond academia have also served to reinvigorate the interest in economic history. As the twentieth century drew to a close, increased globalisation, the rising influence of multinational corporations, and the concurrent trend towards increased inequality caught the attention of scholars whose responses ranged from a sense of rage among many historians to confusion among economists. ${ }^{21}$ Historians at the time lacked a voice in these matters, with Lipartito lamenting that 'at the very time when multinational corporations were reshaping the global economy and nations were embracing neoliberal policies, the economic found scant space in historical writing' ${ }^{22}$ The growing influence of global history, and its links with transnational history and postcolonial studies, has begun to provide historians with frameworks to understand and interpret trends in the international economy. ${ }^{23}$ This literature recognises that no nation is an economic island, with global transmissions - from commodities, to finance, information, and culture - connecting and shaping historical

\footnotetext{
${ }^{21}$ Of particular note has been Thomas Piketty's major contributions, most recently and significantly, Capital in the Twenty-First Century (Cambridge, MA: Harvard University Press, 2013).

${ }^{22}$ Lipartito, 105.

${ }^{23}$ Maxine Berg, Writing the History of the Global: Challenges for the Twenty-first Century (Oxford: Oxford University Press, 2013); Anthony G. Hopkins, Global History: Interactions between the Universal and the Local (New York: Palgrave Macmillan, 2006); Steven C. Topik and Allen Wells, Global Markets Transformed, 1870-1945 (Cambridge, MA: Harvard University Press, 2014).
} 
experiences across vast geographic expanses. At the same time, a more global canvas has found that economic convergence among nations is not inevitable. Indeed, the debate over the last fifteen years about the 'Great Divergence' has truly revived interest in economic history by bringing together a wide range of perspectives and evidence to examine differences in prosperity among nations and regions. ${ }^{24}$

The Global Financial Crisis (GFC) of 2007-8 triggered a massive increase in the popularity of the history of capitalism. Beckert noted: 'since the crisis of 2008 , the amount of public debate on capitalism has skyrocketed' ${ }^{25}$ Public interest translated into rising student interest and enrolments, with Shermer recalling that 'rarely did I find a student who mentioned the Great Depression, Social Security (or Medicare), or unions before 2008. Now, half the class wants to know about the 1930s and the New Deal. ${ }^{26}$ The GFC brought the history of capitalism movement of age, in America at least. ${ }^{27}$ Students of history sought to understand more about the world of economics and business but in a non-technical and critical fashion. They wanted an informed voice and to understand if capitalism as a system was to blame for modern and historic 'problems'.

Economists understood and discussed these trends but were caught off-guard by the timing and severity of the GFC. Coming a decade after the Asian financial crisis, which they

\footnotetext{
${ }^{24}$ For a summary of recent contributions to this literature, see Simon Ville, 'Divergence and Convergence: New and Shifting Paradigms in Comparative Economic History', Australian Economic History Review 55, no. 1 (2015): 80-94.

${ }^{25}$ Sven Beckert et al., 'Interchange: The History of Capitalism', Journal of American History 101, no. 2 (2014): 514.

${ }^{26}$ Beckert et al., 530. See also Jennifer Schuessler, 'In history departments, it's up with capitalism', New York Times, 6 April 2013.

${ }^{27}$ Lamoreaux.
} 
were still trying to work out, the economics profession again failed to anticipate a major and wide-ranging economic shock. 'It's the people schooled in economic history who came to terms with the crisis most readily', Tyler Cowen noted, while others recommended history topics combined with finance and microeconomics as the foundation for future economics training. ${ }^{28}$ As the mood shifted, Carmen Reinhart and Kenneth Rogoff's ironically titled This Time is Different saw common patterns across hundreds of financial crises of many nations over nearly a millennium. ${ }^{29}$ Financial history became a New York Times bestseller. With the aim of contextualising contemporary challenges, economists have begun interrogating the interwar depression with renewed interest. Here and elsewhere, though, they have jumped into what Crafts pejoratively calls 'DIY economic history', which lacks the 'deeper knowledge' provided by economic historians. ${ }^{30}$

\section{Re-establishing economic history as a vibrant interdisciplinary field}

The foregoing account confirms economic history's reliance upon its parent disciplines, while also highlighting the ability to communicate between them as the main strength of the field. Economic history, as it has done in the past, contributes important historical perspectives to the analysis of current economic events, while an economic frame provides a valuable foundation through which complex historical processes may be understood. The future of economic history is in recognising and embracing this interdisciplinary role.

\footnotetext{
28 'How has the Crisis Changed the Teaching of Economics?', The Economist, 17 September 2010.

${ }^{29}$ Carmen M. Reinhart and Kenneth S. Rogoff, This Time is Different: Eight Centuries of Financial Folly (Princeton: Princeton University Press, 2009).

${ }^{30} \mathrm{Crafts}, \mathrm{S} 6$, refers to the tendency of economists to write economic history rather than rely on specialists in the field.
} 
Attempts to shape economic history as a discipline proved largely unsuccessful. The expansion of scholars, students, resources, and innovative research output for the field in the post-WWII decades gave the field a distinctive 'disciplinary' feel, with greater recognition from the academy, government policy, and the public. However, like many disciplines, this pattern of growth bred an inward-looking mentality. ${ }^{31}$ Separate departments of economic history in some nations led to 'damaging compartmentalisation', isolating scholars from their parent disciplines and discouraging connections with other, potentially fruitful, areas of research. ${ }^{32}$ Ironically, the field's disciplinary aims, we believe, were destined to fail. It lacked the capacity to develop departments, graduate programs, conferences, and research material of sufficient scale to sit alongside economics or history. ${ }^{33}$ Secondly, the knowledge base of economic history draws upon its parents to such a degree that makes it unlikely ever to be intellectually distinctive enough as its own, specialised domain of knowledge.

The growing insularity of economic history exposed it to changes in the university sector in the 1990s, when the field was unable to adequately convince external parties of its relevance. Trends towards more professional training within business degrees led to economic history subjects being gradually excised. This meant increasing colonisation of economic historians within economics groups. For those in separate departments, the lack of students meant that most departments were either closed or merged with other groups to facilitate economies of scale. The field lost visibility, student numbers further declined, and

\footnotetext{
${ }^{31}$ Tony Becher and Paul R. Trowler, Academic Tribes and Territories: Intellectual Enquiry and the Culture of Disciplines (Buckingham: The Society for Research into Higher Education, Open University Press, [1989] 2001).

${ }^{32}$ Hudson, 9. See also Coleman.

${ }^{33}$ David Meredith and Deborah Oxley, 'The Rise and Fall of Australian Economic History', in The Routledge Handbook of Global Economic History, eds, Boldizzoni and Hudson (London: Routledge, 2015), 73-94; Hasselberg.
} 
chairs and permanent appointments went unfilled. ${ }^{34}$ Although this period was tumultuous and uncertain for members of the field, we argue that it was cathartic by forcing economic historians to look outwards. The loosening of connections among economic historians exposed them to a range of disciplinary approaches and knowledge, and facilitated the more recent innovations in the subject.

Economic history, it seems, is thus neither a discipline nor a colony. Institutional independence fostered insularity that isolated it from its important disciplinary parents. On the other hand, colonisation imposed a single disciplinary tradition that cut off the field from its other parent. Neither approach was appropriate for economic history as they failed to recognise the field's inherently interdisciplinary nature. Interdisciplinary research (IDR) integrates material from two or more disciplines, producing new ideas or new approaches. It exists on the boundaries and in the empty spaces between disciplines and, by integrating knowledge across these different spaces, it is inherently creative and innovative. ${ }^{35}$ Through its ability to draw on material from diverse areas, IDR also appeals to broad audiences and stakeholders by addressing the complex problems of the modern world - problems that have little respect for traditional disciplinary boundaries. ${ }^{36}$

\footnotetext{
${ }^{34}$ For Australia, see Stephen Nicholas, 'The Future of Economic History in Australia', Australian Economic History Review 37, no. 3 (1997): 267-74. For Britain, see Hudson.

${ }^{35}$ Andrea Bonaccorsi, 'New Forms of Complementarity in Science', Minerva 48, no. 4 (2010): 355-87; Jerry A. Jacobs and Scott Frickel, 'Interdisciplinarity: A Critical Assessment', Annual Review of Sociology 35, no. 1 (2009): 43-65; Ken Fuchsman, 'Rethinking Integration in Interdisciplinary Studies', Issues in Integrative Studies 1, no. 27 (2009): 70-85.

${ }^{36}$ Thomas S. Kuhn, The Structure of Scientific Revolutions (Chicago: University of Chicago Press, [1962] 1970); Catherine Lyall and Laura R. Meagher, ‘A Masterclass in Interdisciplinarity: Research into Practice in Training the Next Generation of Interdisciplinary Researchers', Futures 44, no. 6 (2012): 608-17; Scott E. Page,
} 
While this mode of research can take several different forms, economic history resembles an enduring form of IDR - the semi-permanent interdisciplinary research field (IDRF). ${ }^{37}$ In an IDRF, research is conducted within a certain level of social organisation and institutional organisation, with various activities sustaining contact among members of the field, and between the field's parent disciplines. These communicating infrastructures bring scholars together in the interdisciplinary space, creating ongoing, regular interactions, and assisting the diffusion and integration of knowledge between different groups. ${ }^{38}$

The ability of economic history to engage with both disciplines, and to integrate new, innovative knowledge is one of its main strengths. However, the path of the economic historian can be risky. Members of any IDRF risk a 'career-long bout of cognitive dissonance' borne from holding allegiance to two different disciplinary traditions. ${ }^{39}$ For those in economic history, this effect is compounded by the fact that one parent is a part of the social sciences, and one a part of the humanities. This means economic historians must attempt to reconcile divergent ways of framing questions, of using evidence, and of

The Difference: How the Power of Diversity Creates Better Groups, Firms, Schools, and Societies (Princeton: Princeton University Press, 2007).

${ }^{37}$ Claire Wright and Simon Ville, 'Visualising the interdisciplinary research field: The life cycle of economic history in Australia', Minerva, (forthcoming)..

38 'Communicating infrastructures' ordinarily describe the technology of an electronic or physical network such as wireless radio waves or historical telegraph systems designed to assist communication between individuals and firms. See Gordon Boyce, 'Communicating Infrastructures', in How Organisations Connect. Investing in Communication, eds Gordon Boyce, Stuart Macintyre and Simon Ville (Melbourne: Melbourne University Press, 2002), 28.

${ }^{39}$ Lyons, Cain and Williamson, 37. 
determining answers. ${ }^{40}$ The pluralist methodology of history, however, is valuable in attempting to achieve this.

Finally, members of an IDRF risk some professional roadblocks - although governments and universities extrinsically advocate IDR, it is the unit of the discipline that continues to shape much of the operational behaviour of universities and funding organisations. ${ }^{41}$ Degrees, appointments, and promotions reinforce disciplinary dominance; research evaluation by external bodies favours within-discipline publishing traits; grant awarding committees rely on the disciplinary expertise of assessors; and members of national learned academies are populated by senior members of disciplinary 'tribes' ${ }^{42}$ Much of this systemic bias against interdisciplinary scholars arises because evaluating IDR is challenging, indeed the variety of knowledge involved means most IDR cheerfully resists the development of a single standard. ${ }^{43}$

Economic history is, therefore, characterised by vast opportunities, but serious challenges. For the continued vibrancy and relevance of the field, an integrated approach that takes seriously the contributions of each 'parent' discipline is necessary. Moving forward, we

\footnotetext{
${ }^{40}$ Cipolla.

${ }^{41}$ Peter Woelert and Victoria Millar, 'The 'paradox of interdisciplinarity' in Australian research governance', Higher Education 66, no. 6 (2013): 755-67.

42 Jochen Gläser and Grit Laudel, 'Evaluation without Evaluators: The Impact of Funding Formulae on Australian University Research', in The Changing governance of the sciences: The advent of research evaluation systems, eds R. Whitley and J. Gläser (Dordrecht: Springer, 2007), 127-51; Helga Nowotny, Peter B. Scott and Michael T. Gibbons, Re-thinking Science: Knowledge and the Public in an Age of Uncertainty (Oxford: Oxford Polity Press, 2001); Woelert and Millar.

${ }^{43}$ Julie Thompson Klein, Crossing Boundaries: Knowledge, Disciplinarities, and Interdisciplinarities (Charlottsville: The University of Virginia Press, 1996); Klein, 'Interdisciplinary Needs: The Current Context', Library Trends 45, no. 2 (1996): 134-54.
} 
believe there are several practical steps that can assist the revival of economic history as a scholarly field.

There are several well-defined polarities between scholarship in economics and history, which might be distilled into quantitative versus qualitative, causality versus narrative, inductive versus deductive, and generalisations versus specifics. These polarities, rather than being incompatible opposites, offer different qualities to the examination of a particular research question. Thematic or generalised discussions complement specific texts that analyse a particular time and place in detail; and deductive analysis, by testing the applicability of theory, necessarily hinges on an inductive approach that builds arguments based on historical experience. The key strength of economic history is to utilise a continuum of different approaches between these poles, with the communication, persuasion, and integration of these approaches vital to economic history's role as an interdisciplinary field.

Embracing this spectrum of approaches requires an adjustment of thinking from academic journals, research evaluators, and university hiring and promotion committees. It is particularly dependent on the distribution of comparable rewards for these diverse research efforts. We urge journals and conferences to be open to accepting papers from a wide range of approaches, and to assign appropriate reviewers to evaluate their quality. Research evaluation, and promotions and appointments decisions, should also take seriously the 'integrated whole' of economic history's interdisciplinary work, not merely the value of each individual disciplinary component. ${ }^{44}$

Second, we recommend embracing joint work. Collaboration between scholars with different perspectives increases the diffusion of knowledge between economic historians, and among those in adjacent disciplines. Co-authorship, edited volumes, or joint projects are all

\footnotetext{
${ }^{44}$ Lyn Grigg, Cross-disciplinary Research: A Discussion Paper (Canberra: Australian Research Council, 1999).
} 
important vehicles through which this collaboration may occur. Through the development of an agenda of key themes, economic history could provide a focus to which those from diverse disciplinary backgrounds come together, increasing communication between these groups. This would also pool brainpower and resources, with more scholars working on specific issues increasing the chances of major innovations or breakthroughs in the field. While economic history is a small field between economics and history, well-written work supported by both perspectives always has the potential to reach a large audience, arguably greater than their 'parents'.

Finally, we encourage the field to grow their communicating infrastructures in the form of professional activities that bring members of the field together and in contact with those from adjacent disciplines. This could include joint teaching or graduate supervision, centres for economic history that engage with different faculties or schools, outreach from the societies and conferences to various groups, or the encouragement of diverse editorial boards for the relevant journals. ${ }^{45}$ We stress that strict institutional entities, such as separate departments, are not the only method available to advance economic history. Communicating infrastructures for IDRFs must be porous enough to allow communication and the diffusion of knowledge not only among members of the field, but between the IDRF and its parent disciplines.

\section{What are its prospects in Australia?}

There are many reasons to feel positive about the future of economic history in Australia. Economic history here has been relatively pluralist in approach. The influence of the new

\footnotetext{
${ }^{45}$ There have been a few isolated initiatives such as the Centres for History and Economics at Harvard and Cambridge universities.
} 
economic history from the United States has been tempered by domestic empirical traditions that have helped strengthen its claim to be an independent interdisciplinary research field. Australia's colonial past encouraged the recording of many aspects of development, best illustrated by the work of colonial New South Wales statistician Timothy Coghlan, and national storytelling in the hands of interwar economic historians Edward Shann and Brian Fitzpatrick. ${ }^{46}$ Since WWII, different strands of economic history have competed with one another. The highly influential work of Noel Butlin and colleagues at the Australian National University (ANU) focussed on describing and analysing national income statistics by building a sectoral picture of economic development. ${ }^{47}$ Such inductive work laid the foundations for deductive new economic history in the hands of scholars with links to North America, such as David Pope, Ian McLean, Jonathan Pincus, and Rod Maddock. ${ }^{48}$ A mix of archival research and descriptive statistics characterised the work of Melbourne business and organisational historians particularly Boris Schedvin, Geoffrey Blainey and David Merrett. ${ }^{49}$

${ }^{46}$ William Coleman, 'The Historiography of Australian Economic History', in The Cambridge Economic History of Australia, eds Ville and Withers (Melbourne: Cambridge University Press, 2015), 11-15.

${ }^{47}$ Noel Butlin, Australian Domestic Product, Investment and Foreign Borrowing 1861-1938/9 (London: Cambridge University Press, 1962); Noel Butlin, Investment in Australian Economic Development, 1861-1900 (London: Cambridge University Press, 1964); Colin Forster, Industrial Development in Australia 1920-1930 (Canberra: ANU Press, 1964), Alan Barnard, The Australian Wool Market 1840-1900 (Melbourne: Melbourne University Press, 1958).

${ }^{48}$ Michael Carter and Rod Maddock, 'Leisure and Australian Wellbeing 1911-1981', Australian Economic History Review 27, no. 1 (1987): 30-44; David Pope, 'Price Expectations and the Australian Price Level: 190130', Economic Record 58, no. 4 (1982): 328-38; Ian W. McLean, 'The Analysis of Agricultural Productivity: Alternative Views and Victorian Evidence', Australian Economic History Review 21, no. 1 (1981): 6-28. ${ }^{49}$ Geoffrey Blainey, The Rush that Never Ended: A History of Australian Mining (Melbourne: Melbourne University Press, 1963); C. B. Schedvin, Shaping Science and Industry: A History of Australia's Council for 
Historians of labour markets and industrial relations deployed a range of methods from the quantitative to the archival. ${ }^{50}$ Finally, the enduring influence of government in the history of Australia's economy attracted the interest of policy-minded applied economists such as Bob Gregory, and Glenn Withers. ${ }^{51}$ Although there were, historically, a variety of intellectual traditions in Australia's economic history field, throughout the 1980s the research program more closely resembled the economics discipline. Closer contact with colleagues in economics or business faculties increased the emphasis upon economic theory and econometric techniques. $^{52}$

The dismantling of economic history departments in Australian universities in the 1990s, though disruptive at the time, may well have rescued the 'discipline' from itself. Size certainly matters in scholarly pursuits, and economic history, most would agree, is too small in Australia to endure as a separate discipline ${ }^{53}$ Forcing scholars to look outwards has probably been healthy for the intellectual diversity of the field, while its occupation of the

Scientific and Industrial Research, 1926-49 (Sydney: Allen \& Unwin, 1987); David Merrett, ANZ Bank: An Official History (Sydney: Allen and Unwin, 1985).

${ }^{50}$ David Pope, 'Wage Regulation and Unemployment in Australia, 1900-30', Australian Economic History Review 22, no. 2 (1982): 103-26; Stuart Macintyre, The Labour Experiment (Melbourne: McPhee Gribble, 1989).

${ }^{51}$ Robert G. Gregory and Noel Butlin eds, Recovery from the Depression: Australia and the World Economy in the 1930s (Cambridge: Cambridge University Press, 1988).

${ }^{52}$ For example, see the main collaborative works: Rod Maddock and Ian W. McLean eds, The Australian Economy in the Long Run (Cambridge Cambridge University Press, 1987); Robert G. Gregory and Noel G. Butlin eds, Recovery from the Depression: Australia and the World Economy in the 1930s (Cambridge: Cambridge University Press, 1988).

${ }^{53}$ A recent estimate suggested a small number (35) and low density of economic historians in Australia. See Joerg Baten and Julia Muschallik, 'The Global Status of Economic History', Economic History of Developing Regions 27, no. 1 (2012): 93-113. Meredith and Oxley, 78, suggest a lower figure again of maybe 15. 
space between its parent disciplines assists those disciplines to communicate with broad stakeholders in a relatively small and isolated national community.

While Douglas Copland's oft-quoted epithet, 'Australian history is, of course, largely economic history' is certainly contestable, the struggle for survival, in their different ways, by both settler and Aboriginal shaped their lives so as to focus on the secular, the 'here and now', the material. Not only did Coghlan and others seek to record progress, but the engagement of the academic with the real world of economic wellbeing remains strong today, with many contemporary economic and business commentators and journalists offering their economic historical adumbrations of our present dilemmas. ${ }^{54}$

The powerful impulses felt among American economists and historians from the GFC, nonetheless, barely caught the attention of an Australian community largely unaffected by this major event. ${ }^{55}$ However, the intrusion of the real world of economic progress is now impinging more closely on the academy in Australia. Rather than the sudden shock of a financial crisis, the challenge facing Australia is the sense of standing at a crossroads in our economic development. We are at a prescient time to reflect on our economic history and how it might guide our future directions. Behind us lies one of the longest and most prosperous economic booms in Australian history - now a quarter of a century in length. Ahead of us we face uncertainty, wondering what sources of progress might replace the largely extinguished mining boom. ${ }^{56}$ Maybe farming will lead a 'dining boom' to feed the

\footnotetext{
${ }^{54}$ Witness the number of writers on economic history from outside the academy. Paul Cleary, Too Much Luck: The Mining Boom and Australia's Future (Melbourne: Black Inc., 2011); Peter Hartcher, The Sweet Spot: How Australia Made Its Own Luck-and Could Now Throw it All Away (Melbourne: Black Inc., 2014); George Megalogenis, Australia's Second Chance (Melbourne: Penguin, 2015).

${ }^{55}$ Besides self-congratulatory mention of effective regulatory systems and well-timed stimuli.

${ }^{56}$ John Edwards, Beyond the Boom (Melbourne: Penguin, 2014).
} 
expanding Asian middle classes, or perhaps the recent expansion in business and education services will continue ${ }^{57}$ Historical parallels are also drawn by a desire to reflect on the outcomes of the extended period of unbroken growth, which has led to the increasingly unequal distribution of wealth and the gradual but belated closing of the gap between white and indigenous Australians. ${ }^{58}$

The external impulse, perhaps a decade later than elsewhere, the pluralist tradition, and the refreshed interdisciplinary opportunities for economic history in Australia might suggest an epiphany for the field in the coming years. What form this might take we cannot be sure except that it will not be the same field that rose to prominence after WWII. Scholarly, organisational and external influences have all shifted considerably. In the previous section, we argued for work that genuinely brings together different approaches to economic history drawing on both economics and history. Australia is particularly well placed to prosecute this approach given the diverse methods of economic history here and the permeable boundaries between disciplines in a small community.

In some respects, Australian economic history can play catch up with trends already occurring overseas and seek out ways of building on those successes. The history of capitalism literature in America has been largely written by historians with little reference to the methods and ideas of economics or management. Engagement with the history of capitalism movement would be consistent with a sustained interest in business history in Australia. Australian business historians have tended to shy away from the use of the term

\footnotetext{
${ }^{57}$ Joel Fitzgibbon, 'We Need a Cash Cow for the Dining Boom', The Huffington Post, 6 May 2016.

${ }^{58}$ Anthony B. Atkinson and Andrew Leigh, 'The Distribution of Top Incomes in Australia', Economic Record 83, no. 262 (2007): 247-61; Jon C. Altman, Nicholas Biddle and Boyd H. Hunter, 'Prospects for 'Closing the Gap’ In Socioeconomic Outcomes for Indigenous Australians?', Australian Economic History Review 49, no. 3 (2009): 225-51.
} 
'capitalism' because of its traditional association with manufacturing industry, a sector of lesser importance in Australia. ${ }^{59}$ In addition, it was regarded as a value laden term with negative connotations about business that sat uneasily with largely agnostic, sometimes apologetic, historians of business. As we saw earlier, the purview of the term has now broadened considerably. While from the pens of some recent writers, capitalism still foments struggle and injustice, overall it has become more mainstream. Critical management studies and management history, specifically addressing the organisation and historical practice of management, have been notable growth areas in Australian business faculties in recent years and would also provide valuable insights for the history of capitalism. Much of their work is interdisciplinary in nature and includes scholars who have diversified their intellectual toolkit from labour history and industrial relations. ${ }^{60}$ Similarly, accounting history has emerged in the last twenty years as a strong interdisciplinary field in Australia with its own specialist journal, Accounting History.

The study of consumption, an area that tends to be neglected by economic and business historians, provides further opportunities to contribute to our understanding of markets. ${ }^{61}$ Historians, primed with their understanding of the mental models that affect the decision-making of individuals, would be well placed to work with economic historians in reconnecting supply with demand. Marketing historians in Australia, some of whom are beginning to cross the binary divide between producers and consumers, also have an

\footnotetext{
${ }^{59}$ Although see Philip McMichael, Settlers and the Agrarian Question: Capitalism in Colonial Australia (Cambridge: Cambridge University Press, 1984); Andrew Wells, Constructing Capitalism: An economic history of eastern Australia, 1788-1901 (Sydney: Allen \& Unwin, 1989).

${ }^{60}$ Many of the members of the Work and Organisational Studies discipline at University of Sydney fall into this category.

${ }^{61}$ Although see Greg Whitwell, Making the Market: The Rise of Consumer Society (Melbourne: McPhee Gribble, 1989).
} 
important role to play. ${ }^{62}$ There remains much to learn about the different behaviour patterns of consumers in the cities and the bush and also what historians of international business understand about multinational attitudes to the Australian consumer. Relatedly, the role of women, as either producers or consumers, has been largely neglected by economic historians in Australia. ${ }^{63}$

To date, Australian contributions to global history and the Great Divergence debate have sat somewhat on the periphery, arguing the Australian corner rather than developing a broader global context. ${ }^{64}$ While contributions to the Great Divergence have tended to be adversarial - conclusions reached by the historical methodologies of the Californian School are at odds with those drawn by the more quantitative approaches of the Europeanist - we call for an Australian led initiative integrating both approaches within a single project that views each as part of the overall story. It would be valuable to decide where Australia fits best into the global story in terms of types of development, directions of connection, and communication. The settler, the colonial and the natural resource contexts may well be the

\footnotetext{
${ }^{62}$ Robert Crawford and Kim Humphery, Consumer Australia: Historical Perspectives (Newcastle upon Tyne: Cambridge Scholars Publishing, 2010). See also the special issue of Journal of Historical Research in Marketing 8, no. 3 (2016), which focusses on Australia.

${ }^{63}$ Important exceptions are Katrina Alford, Production or Reproduction? An Economic History of Women in Australia (Melbourne; OUP, 1984); Deborah Oxley, Convict Maids: the Forced Migration of Women to Australia (Cambridge: Cambridge University Press, 1996).

${ }^{64}$ Ian W. McLean, Why Australia Prospered: The Shifting Sources of Economic Growth (Princeton, NJ: Princeton University Press, 2013); Barrie Dyster and David Meredith, Australia in the Global Economy: Continuity and Change (Cambridge: Cambridge University Press, 2012).
} 
most fruitful lines of inquiry. ${ }^{65}$ While each of these approaches particularly looks back towards Australia's colonial past, topics that address current debates about our role in the Asian century might motivate renewed interest in more recent history, when the 'prospects of proximity' to Asia began to supersede the tyranny of distance from Britain.

This provides an opportunity for economic historians to work with Asian historians whose interest in economic issues has been spurred by the catch up experienced by the likes of Japan, China, and the Asian Tigers of Hong Kong, Singapore, South Korea, and Taiwan. Over the last decade, two initiatives of the Economic History Society of Australia and New Zealand signalled a determination to look beyond geographic as well as disciplinary borders - the introduction of a successful annual international conference, the Asia-Pacific Economic and Business History Conference, and the expansion of the Australian Economic History Review to become a regional journal in subtitle and content. ${ }^{66}$ There are opportunities to extend this initiative to make the most of the buoyant state of economic and business history in Japan. ${ }^{67}$ Other healthy economic history communities in Spain, Belgium, Sweden, and

\footnotetext{
${ }^{65}$ Relevant existing work includes Donald Denoon, Settler Capitalism. The Dynamics of Dependent Development in the Southern Hemisphere (Oxford: Clarendon, 1983); Chris Lloyd, Jacob Metzer, and Richard Sutch, eds, Settler Economies in World History (Leiden: Brill, 2013).

${ }^{66}$ There has been a rise in articles in non-Australian content, and an increase in the number of issues per year. See Stephen Morgan and Martin Shanahan, 'The supply of economic history in Australasia: The Australian Economic History Review at 50', Australian Economic History Review 50, no. 3 (2010): 217-23; Meredith and Oxley, 85 .

${ }^{67}$ Japan currently has the largest number of economic historians, with over 2,000 scholars registered with the main professional bodies. See Sugihara.
} 
Latin America offer similar opportunities for collaboration and comparison, while also presenting an optimistic case for the future of economic history in Australia. ${ }^{68}$

Part of the renewed interest of Australian historians with economic history relates to the growth of digital humanities and the use of big data that connects with broader social questions particularly of demography and health. A recent issue of Australian Historical Studies discussed the availability and use of digital records in such areas as slave ownership, convict workers and living standards of military personnel. ${ }^{69}$ As we saw above, economic history in Australia has a strong inductive quantitative tradition. Without necessarily using inferential analysis, digital humanities provide a closer connection to both the quantitative and econometric traditions of economic history, complementing the existing strengths of the field and reaffirming the notion that economic history is helping to fill the interdisciplinary void.

However, alongside promising opportunities, economic history also faces challenges. While the enforced return to the interdisciplinary space from the late 1990s brought new opportunities, it has involved loss of influence, resources and positions in economic history. The support of initiatives, particularly at ANU, that helped publicise its work and engage with international economic history through working paper series and international visitor programs, are now harder to come by. There is thus a risk of loss of visibility at a time when global reach and potential for methodological innovation is growing. However, strong national organisations, mentioned above, and selective research nodes, such as the Centre for

\footnotetext{
${ }^{68}$ Iriarte-Goni; Aerts and Bosma; Hasselberg; Luis Bertola and Javier Rodriguez Weber, 'Latin American economic history: Looking backwards for the future', in The Routledge Handbook of Global Economic History, eds, Boldizzoni and Hudson (London: Routledge, 1987), 329-42.

${ }^{69}$ Australian Historical Studies 47, no. 3 (2016)
} 
Economic History at ANU and the McComish Fund for Economic History at Trinity College, University of Melbourne, arguably provide a viable, more focussed institutional structure.

Several recent developments in Australian economic history are suggestive of a partial return to colonisation by economics. These include appointments into economic history posts of younger scholars predominantly trained in economics in North America and with broad economic research agendas. This is reinforced at ANU by the cliometric orientation of the Centre for Economic History. In addition, the recent creation of $\mathrm{OzClio}$, whose bi-annual meetings (Australasian Cliometrics Workshop), are refreshingly focussed on in depth discussion, is largely oriented towards a quantitative and econometric approach to economic history. $A^{*}$ rankings for those leading econometric history style journals have reinforced the emphasis on this approach within business faculties for whom journal ranking evaluation remains de rigueur. Likewise, cultural history remains the dominant form of historical research and teaching in Australian universities, which continue to provide a wide range of cultural history topics but, despite the fact that Australian history is offered by thirty-four tertiary institutions, none teaches a subject on economic history. ${ }^{70}$

However, balancing this, there is evidence of a younger generation of historians with an interest in economic matters entering the field. Recent recipients of Australian Research Council early career awards and university postdoctoral schemes at a range of different universities, including Sydney, Wollongong, Deakin and Australian Catholic University, are addressing topics such as shipping, air transport, railways, urban development, and the professions. In particular, the Laureate Research Program in International History at

\footnotetext{
${ }^{70}$ Chris Berg and Stephanie Forrest, 'The End of History...in Australian Universities' (Melbourne: Institute of Public Affairs, 2015).
} 
University of Sydney is concerned with globalisation and economic ideas and is home to a number of postdoctoral fellows and graduate students.

Irrespective of whether economic history has attracted more adherents from economics or history recently, what is clear is that we can no longer estimate the size of the field mostly in terms of self-declared economic historians, of which there are certainly declining numbers. Instead, it is working 'on' rather than 'in' economic history that matters. On that basis, we are probably better advised measuring the output of research with substantive economic history content than the number of specialist practitioners. This, of course, is not a simple task. However, one starting point would be to search the last three years of publications (2014-16) in the six principal Australian-based economics and history journals for papers with substantial economic history content. ${ }^{71}$ This reveals twenty-one papers with thirty-four authors, most of whom would not consider economic history to be their primary research field. In the same period, thirty-six papers by sixty-one authors were published in the Australian Economic History Review. Thus nearly 40 per cent of economic history journal article content in recent years has been published in either economics or history journals. This evidence also points to a more optimistic picture of the field compared with nearly thirty years ago. These ninety-five authors working 'on' economic history in 2014-16 contrasts to fifty-one writing for the same journals during the 1987-89 triennium.

Finally, recent trends in economic history articles in the Australian Economic History Review confirms greater diversity of content in the field in recent years: Morgan and Shanahan found that in the 1960s, eight thematic categories accounted for most output, now

\footnotetext{
${ }^{71}$ Namely Economic Record, Australian Economic Review, Australian Economic Papers, Australian Historical Studies, Australian Journal of Politics and History, and History Australia. We define 'economic history content' as any paper that discusses the development of the economy, an industry, or a firm over time (more than twenty years).
} 
twenty-five categories have relatively substantial shares. The expansion is most notable in business history, marketing, advertising, accounting, market structure, firm strategy, economic development, transport, trade, energy, and technology. ${ }^{72}$ While this more diverse intellectual base is a strength of economic history, its pluralism or 'open architecture' can also be a source of fragmentation and contention. ${ }^{73}$ At a time when substantial opportunities appear to be opening up for economic history in Australia and everyone wants to have a say, the overarching need is to find ways to evolve that seek common agendas, are respectful of different approaches to such questions and, where possible, develop complementary research teams that draw widely on the many techniques that can further our understanding of the economic history of Australia and its place in the global economy.

\section{Conclusion}

Whether it is called millennium economic history or the new materialism, a re-imagined economic history is back. Reports of its death were exaggerated; only the discipline disappeared from view. Its wayward parents, economics and history, have been reconciled, somewhat. The chasm that once divided them has narrowed to an interstice that a re-engaged economic history has the opportunity to bridge.

There is cause for guarded optimism about the future of economic history in Australia in particular. Like the small open economy seeking key trading partners that is modern Australia, economic history as a small heterogeneous field is at its best when building connections with its closest major disciplines. Manoeuvred back into this role in the last

\footnotetext{
${ }^{72}$ Morgan and Shanahan, 225-27.

${ }^{73}$ Geoffrey Jones, Marco H. D. van Leeuwen and Stephen Broadberry, 'The Future of Economic, Business and Social History', Scandinavian Economic History Review 60, no. 3 (2012): 227.
} 
decade and a half by intellectual and institutional shifts has presented the opportunity for a renaissance. Such opportunities are few and far between, and by re-establishing its role as a vibrant and relevant interdisciplinary field, economic history would be wise not to squander this one.

Simon Ville

University of Wollongong

Email: sville@uow.edu.au

Claire Wright

University of Wollongong

Email: clairew@uow.edu.au 